\title{
Central Places and Periodic Markets in the Southeastern Part of the Surrounding Area of Seoul
}

\author{
Hiroshi MorikawA* and Jun-Yong SunG**
}

\begin{abstract}
Studies of periodic markets have hitherto been discussed from locational and socio-cultural points of view concerning their bases of existence. Such discussions were focused on merchants and the organizing systems of periodic markets. However, since not only merchants of periodic markets but also the patrons are important for the existence and continuance of periodic markets, a study of patrons ought to be an alternative approach. Periodic markets in present day Korea are situated as central places of the lowest order and retain a part of their functions, so that they should be discussed as a part of the central place system in Korea.

In the previous research about central places and periodic markets in the surrounding area of Kongju, Chungcheongnam Do, it was considered that periodic markets were mainly supported by peasants inhabiting the surrounding areas because periodic markets have both the functions of purchasing and collecting.

In this survey area full-time and side-business peasants stay at periodic markets for a longer time in order to sell their agricultural products. Therefore, a close relationship between the periodic market and the peasant can be found in this area as well as in the previous survey area. As central places of lower order in Japan also retained the collecting functions of agricultural products until the Second World War, we should not say that the Korean periodic market is very unique.

The use of periodic markets has decreased substantially in the past ten years. However, central functions of low order remain in the settlements where periodic markets once stood. This fact indicates that a new system of central places is being formed.
\end{abstract}

\section{Introduction}

In their previous paper titled "Central Places and Periodic Markets in the Surrounding Areas of Kongju in Chungcheongnam Do, Korea" the authors considered periodic markets as central places of the lowest order in the Korean central place system and investigated the reasons for the continuance of these markets by analysing market patrons (Morikawa and Sung, 1982). This approach was in contrast to the sociocultural and locational approaches presented in previous papers (Ishinara, 1977; MoriKawa, 1980 , pp. $145-165$.)

As a result, the authors concluded that periodic markets definitely functioned as a part of the central place system and closely connected peasants inhabiting the surrounding areas with purchasing and selling activities. Therefore the authors estimated that not only periodic markets but also the central places of lower order themselves will decline with the decrease of rural population and with the modernization of the selling system of agricultural products.

At the same time the authors were confronted with many important questions raised as a result of their previous research and felt that more detailed analyses were required. From where do peasants obtain the goods and services they need? How do they sell their agricultural products to stores, chains of agricultural cooperatives or periodic and permanent markets? By whom and to what extent are periodic and permanent markets utilized?

* Department of Geography, University of Hiroshima, Higashisenda-machi, Naka-ku, Hiroshima 730, Japan.

** Department of Geography Education, Chungbuk National University, Cheongju 310, Korea. 
How do peasants behave in a periodic markets? In addition, it is important to clarify how the central place system changed after the abolition of periodic markets.

Although the authors were unable to answer all of these questions in this research, they feel that their study of Korean periodic markets and the central place system is broadened by the increased research examples with slightly varying conditions.

\section{Characteristics of the survey area}

The survey area with 200,000 inhabitants living in an area of 980 square kilometers is a slender one located along a national highway extending southeastward from Seoul (Figure 1). Yicheon and Umseong $u p s^{1)}$ are located about $50 \mathrm{~km}$ and $95 \mathrm{~km}$ from Seoul, respectively. Although most parts of this area are locationally a match for the Tokyo metropolitan area in Japan, rural characteristics are dominant; the ratio of peasants is over $50 \%$ and their landholdings are as large as 1.44 ha on the average (Table 1).

A national highway passes through the central part of both guns. Express and nonstop buses for Seoul from Yicheon $u p$ and nonstop buses for Seoul and Cheongju from Umseong up run frequently. Within the survey area there is no area with unfavorable traffic conditions. As JEON (1983) has pointed out, the number of nonstop buses, inner-city buses and Saemaul buses have remarkably increased in the period 1965 to 1980 .

The population of the survey area has decreased so greatly in the past five years that the population structure of this area is significantly different from that of the Tokyo metropolitan area with population growth by obvious extention of its suburban area. The population of Yicheon gun increased 24.6\% between 1971 and 1976, however, the population decreased $16.0 \%$ during the following five year period (1976-1981). The population in Soi $(-23.0 \%)$ and Wonnam $(-21.0 \%)$ in

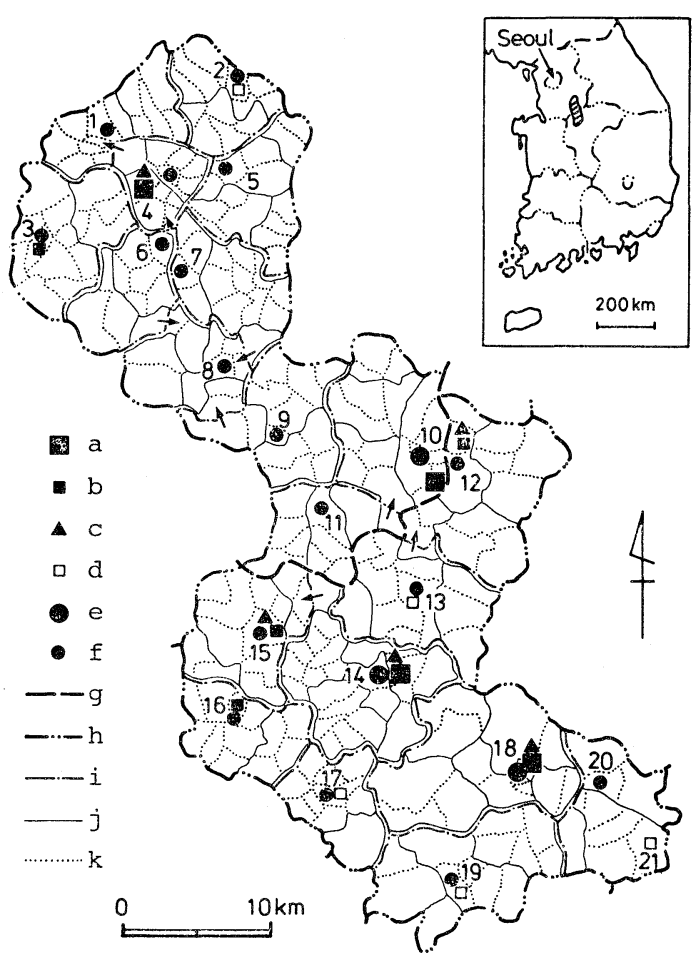

Figure 1. The distribution of periodic and permanent markets and administrative offices.

\begin{abstract}
a: Permanent market b: Periodic market c: Cattle market d: Abolished market e: $U p$ office f: Myeon office $\mathrm{g}$ : Boundary line of do h: Boundary line of gun $\mathrm{i}$ : Boundary line of myeon $\mathrm{j}$ : School district $\mathrm{k}$ : Boundary line of $r i$. Name of myeon or $u p$ : 1. Shindun 2. Baiksa 3. Majang 4. Yicheon 5. Bubal 6. Hobup 7. Daewol 8. Moga 9. Sulseong 10. Janghowon 11. Yul 12. Gamgok 13. Saengguk 14. Kumwang 15. Samseong 16. Daeso 17. Maengdong 18. Umseong 19. Wonnam 20. Soi 21. (Hancheon)
\end{abstract}

Table 1. Population, households and farmhouses in Yicheon and Umseong guns.

\begin{tabular}{|c|c|c|c|c|c|c|c|c|c|c|c|}
\hline & $\begin{array}{l}\text { area } \\
\mathrm{km}^{2}\end{array}$ & $\begin{array}{l}\text { popula- } \\
\text { tion } \\
1981\end{array}$ & $\begin{array}{l}\text { popula- } \\
\text { tion } \\
\text { density }\end{array}$ & $\begin{array}{l}\text { no. of } \\
\text { house- } \\
\text { holds }\end{array}$ & $\begin{array}{l}\text { no. of } r \\
\text { farm- } f \\
\text { houses }\end{array}$ & $\begin{array}{l}\text { ratio of } \\
\text { farm- } \\
\text { houses }\end{array}$ & $\begin{array}{l}\text { mean per- } \\
\text { sons per } \\
\text { household }\end{array}$ & $\begin{array}{l}\text { landhol- } \\
\text { ding per } \\
\text { farmhouse }\end{array}$ & $\begin{array}{l}\text { ratio of } \\
\text { arable } \\
\text { land }\end{array}$ & $\begin{array}{r}\text { popul } \\
\text { increa } \\
1971 / 76\end{array}$ & $\begin{array}{l}\text { lation } \\
\text { ase }(\%) \\
1976 / 81\end{array}$ \\
\hline Yicheon gun & 462.6 & 111,122 & 240 & 22,890 & 12,842 & $56.1 \%$ & 4.85 & 1.54ha & $42.7 \%$ & +24.6 & -16.0 \\
\hline Umseong gun & 517.6 & 94,677 & 183 & 19,201 & $13,767^{*}$ & $* 71.2$ & 4.93 & 1.35 & 35.9 & -1.9 & -14.5 \\
\hline total & 980.2 & 205,799 & 210 & 42,091 & 26,609 & 63.2 & 4.89 & 1.44 & 39.1 & 11.0 & -15.3 \\
\hline
\end{tabular}

Source: Main statistics of myeons and ups (1982) in both guns

* Umseong statistical yearbook (1980). 
Umseong gun and Yul (-21.5\%) in Yicheon gun decreased over $20 \%$ in the same period (1976-1981) as shown in Figure 2. Considering the adoptation of Kaso-ho in Japan (the Depopulation Act) for areas with population decreases of over $10 \%$ within five years and in poor financial condition, we can understand how remarkably the population of this area has decreased. The regional variation of population density in each myeon and $u p$ is relatively slight as seen from $973 / \mathrm{km}^{2}$ in Yicheon $u p$ to $118 / \mathrm{km}^{2}$ in Wonnam myeon. There are no areas with a population density lower than 50 persons as there are in depopu-

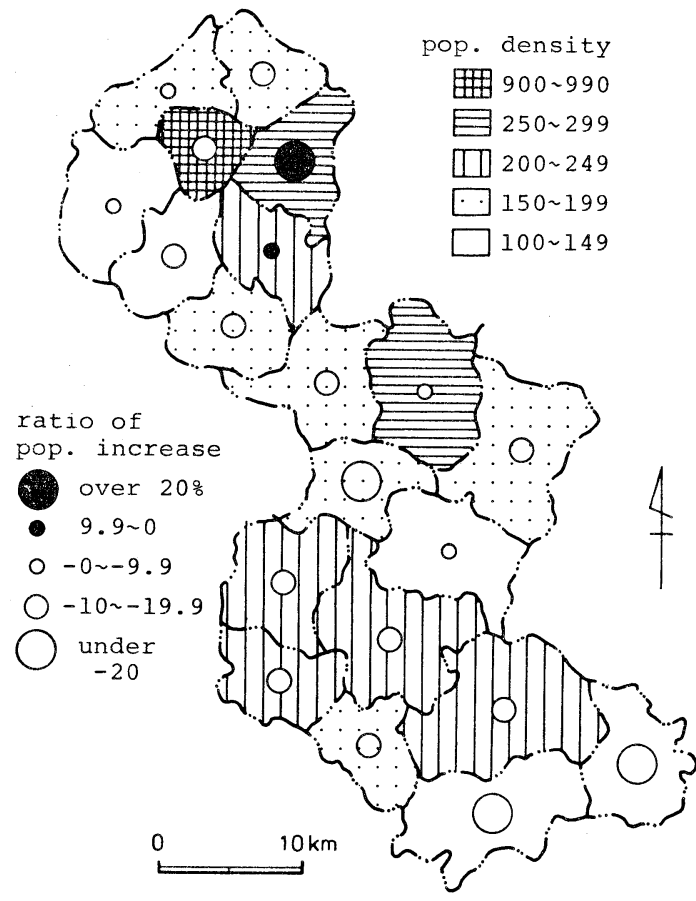

Figure 2. Population density (1981) and the ratio of population increase(19761981) in each $u p$ and myeon.

Source: Main statistics of myeons and ups (1982) in both guns lated areas of Japan.

Many of the inhabitants of the survey area have their relatives in Seoul; the mean ratio of that for each school district accounts for $68.1 \%$. Only a few workers commute to Seoul and commuter facilities have not been well developed. Furthermore, Seoul plays only a small role in the purchasing of goods ${ }^{2)}$ and at present this role seems to be decreasing in comparison to more than ten years ago. Therefore, in spite of its immense size with a population of $8,370,000$ persons it cannot be said that the suburbanization of Seoul has yet expanded to the survey area, though there is

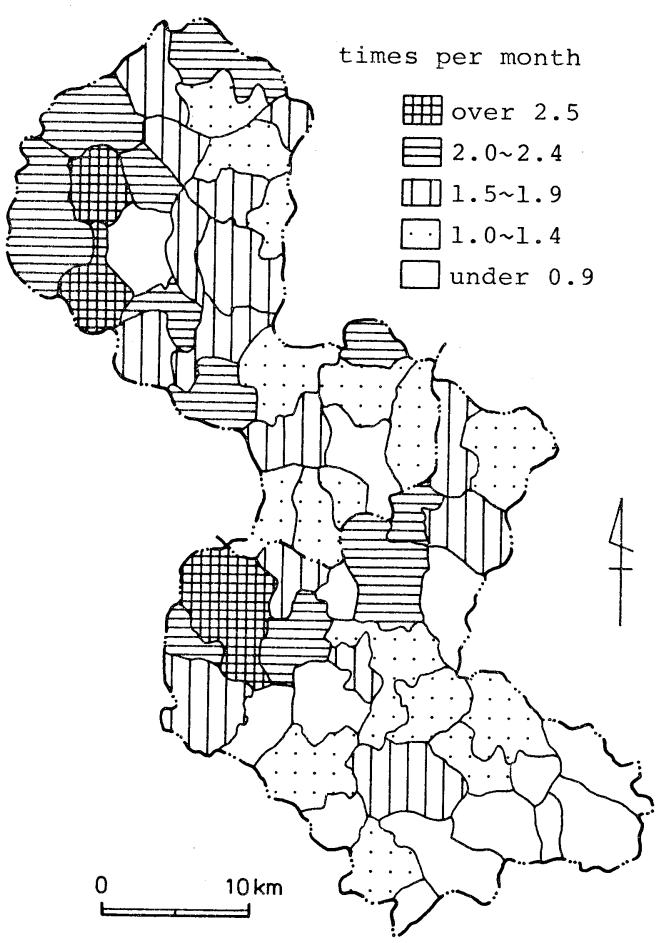

Figure 3. The mean visiting frequency to Seoul for each myeon.

Source: after the questionnaire

Table 2. Administrative dongs ( $r i)$ and natural villages in Yicheon and Umseong guns.

\begin{tabular}{lccccccc}
\hline \hline & $\begin{array}{l}\text { no. of ups } \\
\text { and } \\
\text { myeons }\end{array}$ & $\begin{array}{l}\text { mean pop. } \\
\text { per up } \\
\text { and myeon }\end{array}$ & $\begin{array}{l}\text { no. of ad- } \\
\text { ministra- } \\
\text { tive dongs }\end{array}$ & $\begin{array}{l}\text { no. of } \\
\text { natural } \\
\text { villages }\end{array}$ & $\begin{array}{l}\text { no. of na- } \\
\text { tural villa- } \\
\text { ges per up } \\
\text { and myeon }\end{array}$ & $\begin{array}{l}\text { nof of natural } \\
\text { administrative }\end{array}$ & $\begin{array}{l}\text { no. of house- } \\
\text { holds per na- } \\
\text { tural village }\end{array}$ \\
\hline Yicheon gun & 11 & 10,102 & 269 & 329 & 29.9 & 1.22 & 69.6 \\
Umseong gun & 9 & 10,520 & 231 & 553 & 61.4 & 2.39 & 34.7 \\
total & 20 & 20,622 & 500 & 882 & 44.1 & 1.76 & 47.7 \\
\hline
\end{tabular}

Source: Main statistics of myeons and ups (1982) in both guns 
regional differentiation in a north-south direction; the visiting frequency to Seoul is higher in Yicheon gun than Umseong gun, as shown in Figure 3.

In this area there exist no large cities other than the four small towns such as Yicheon $(26,320$ persons in 1981), Janghowon $(17,806)$, Umseong (19,944) and Gumwang (16,113). The nearest cities to this area are Wonju city $(142,421)$ located $26 \mathrm{~km}$ east of Umseong up and Cheongju city $(275,944)$ located $35 \mathrm{~km}$ to the west.

Hilly mountains with gentle slopes are dominant in Yicheon gun which is known as the area which produced the rice offered to the kings of the Lee Dynasty, whereas in Umseong gun mountains occupy so large an area that settlements and arable lands are located mainly in small valleys and basins.

Table 2 shows 20 myeons and ups which consist of a total of 882 natural villages. In comparison with the considerably larger natural villages of 70 households on the average in Yicheon gun, those of mountainous Umseong gun are very small with 35 households. Accordingly, an administrative dong, administrative area on lower order in myeon and $u p$, is formed by 1.2 natural villages in Yicheon gun compared to 2.4 natural villages in Umseong gun.

\section{The distribution of periodic markets and their rise and fall}

Periodic markets in this area are distributed as shown in Figure 1. MUN (1941, p. 11) revealed that many of the periodic markets in Korea were distributed at intervals from 12 to $20 \mathrm{~km}$ which were distances which could be travelled in one day on foot. Jeon (1982) indicated that the mean service area of a periodic market was $7 \mathrm{~km}$ in radius. However, periodic markets in this survey area are not as equally distributed. As only three periodic markets in Yicheon gun are now active, the people living in the southern villages, such as Moga and Seolseong myeons, cannot reach any periodic market within $7 \mathrm{~km}$. This condition is similar to such myeons as Maengdong, Wonnam and Soi in Umseong gun where periodic markets were abolished recently. On the other hand, periodic markets such as Muguk, Samseong and Daeso are so closely distributed that they are in competition with each other. In particular, Janghowon and Gamgok markets are connected by a bridge established on the boundary line between Gyeonggi and Chungcheongbuk Dos. The periodic market of Janghowon was famous for rice and cattle; though Gamgok originally was a small market, it has been growing since 1977 due to "a movement of developing small towns".3) The cattle market of Janghowon has moved to Gamgok in 1977. These conditions indicate that periodic markets in the survey area are not only disproportionately distributed but also are not oriented to equitable distribution.

Naturally, not all periodic markets are of the same scale. Mun (1941, pp. 137-139) classified periodic markets in the Korean Peninsula before the Second World War into four classes by means of annual turnovers. According to his classification, the periodic markets of Yicheon, Umseong and Muguk belonged to the central market type serving the gun (type B), whereas those of Samseong, Janghowon and Hancheon were classified as central markets serving several myeons (type C). The rest belonged to type C or D. The daily turnovers in 1976, however, do not correspond to such classifications; Janghowon has the largest turnover (Table 3). Corresponding to KIM's statement (1977, pp. 224-226) that periodic markets with daily turnovers of under one million won tend to decline rapidly, all of them in this area were ceased to exist by 1982.

Although the abolishment of small periodic markets began at approximately the same time in this area as in the previous survey area, the present survey area is characterized by the existence of many permanent markets. Permanent markets have already been established in four $u p s$; Yicheon, Janghowon, Muguk and Umseong. They are believed to have grown from large periodic markets and even now retain the function of periodic markets. On market days the turnover of permanent markets also increases. Some of the periodic markets have the function of cattle markets as shown in Figure 1. But small cattle markets 


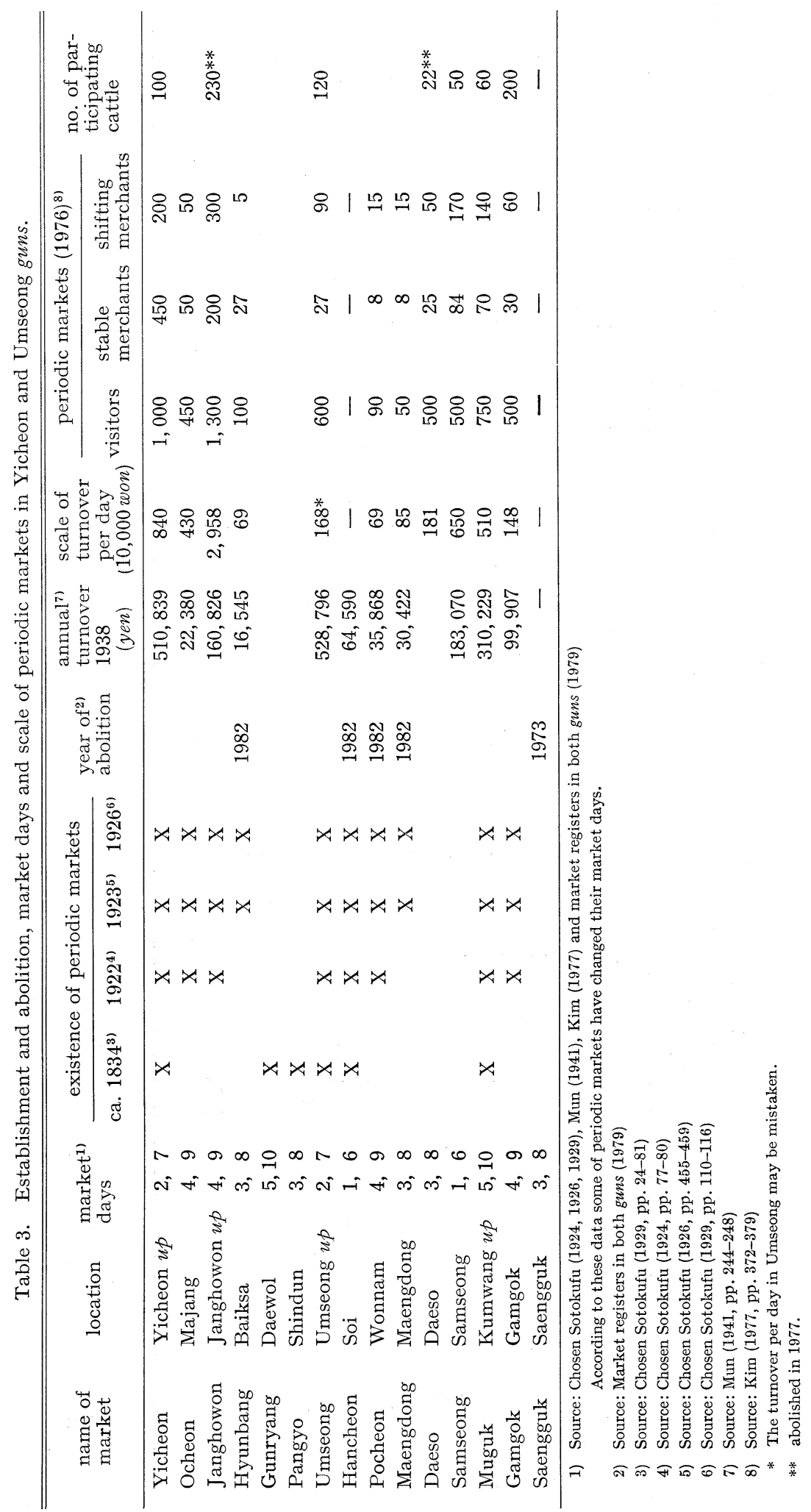




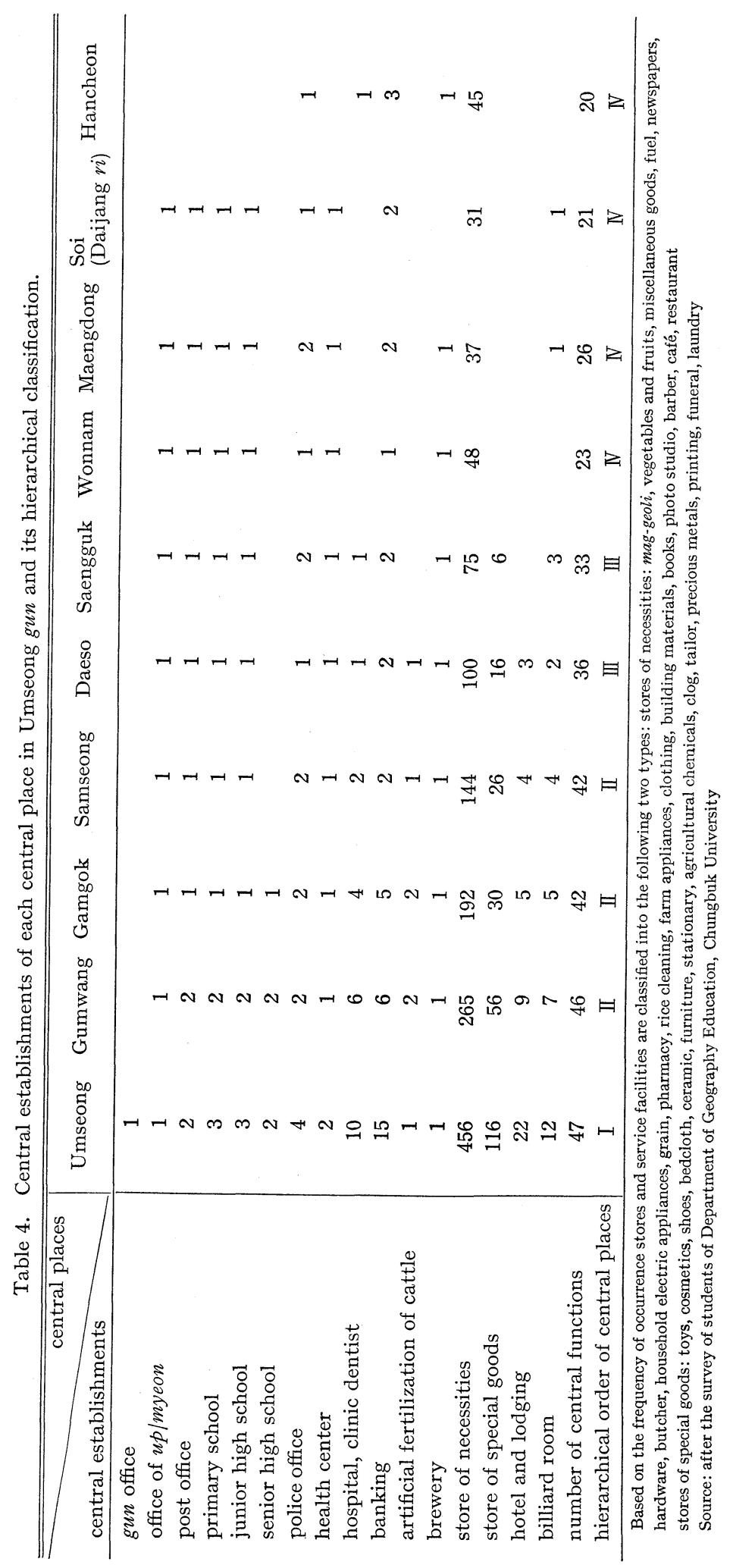


such as Samseong and Muguk have rather limited activity at present.

Table 4 shows the central functions and central establishments of each central place in Umseong gun. Although it is difficult to strictly classify each central place into several orders because there is no clear distinction in its central functions and central establishments, four classes can be obtained by a tentative classification. The relationship between the functional scale of a periodic market and the centrality of each central place as shown in Table 4 is particularly evident. In previous research the authors pointed out the existence of such close relationships mainly in central places of lower order. In Umseong gun, however, it is recognized that central places of a relatively higher order such as Umseong, Kumwang, Gamgok and Samseong have more active functions of periodic markets than central places of lower order which sometimes lack periodic markets. As Table 4 shows, the administrative settlement of Saengguk myeon which no longer has a periodic market does have central establishments similar to Daeso which still holds a periodic market. The settlements of Maengdong, Wonnam and Soi (Jungdong ri) which have no periodic markets also hold to some extent central establishments for daily necessities. Moreover, it is recognized in Soi myeon that Hancheon $r i$ which no longer has a periodic market does have the central function of almost the same order as the administrative settlement of this myeon.
Thus, contrary to the previous conclusion that the exsistence of a periodic market mainly supports central places of low order, the authors consider that the agglomeration of some central functions to administrative settlements has taken place irrespective of the existence or non-existence of a periodic market in each myeon.

\section{Central places and their service area}

\section{The surveying method and its procedure}

Similar to the previous study the authors distributed 2,336 questionnaires to 59 primary schools in all parts of Yicheon and Umseong guns and obtained 2110 significant responses (responsing ratio of 90.3\%). The completed questionnaires were calculated according to school districts: areas which do not necessarily correspond to the boundary lines of myeons and ups. 35.8 questionnaires were obtained on the average per school; the Chungdo branch school, Soi myeon, provided the smallest response with only 14 completed questionnaires.

The authors asked for the name of an administrative dong for purchasing and utilizing. When only the myeon name was described in the responses the authors grouped the myeon in order within the data processing. ${ }^{4)}$

In this paper the service area of each central place is shown by the iso-dependence lines of 30 and $60 \%$. This method represents the features of the service areas more accurately than the arrow method usually used, because it considers the service area whose central

Table 5. The comparison of purchasing features between the present time (A) and ten years ago $(B)$.

\begin{tabular}{|c|c|c|c|c|c|c|c|c|c|c|}
\hline & \multicolumn{5}{|c|}{ purchase on market days $(\%)$} & \multicolumn{5}{|c|}{ purchase without market days $(\%)$} \\
\hline & $\mid \begin{array}{r}\text { periodic } \\
\text { market }\end{array}$ & $\begin{array}{l}\text { permanent } \\
\text { market }\end{array}$ & $\begin{array}{l}\text { permanent } \\
\text { store }\end{array}$ & $\mathrm{t}\left|\begin{array}{l}\text { agricultural } \\
\text { cooperative }\end{array}\right|$ & total & $\begin{array}{l}\text { permanent } \\
\text { store }\end{array}$ & $\left|\begin{array}{l}\text { permanent } \\
\text { market }\end{array}\right|$ & $\begin{array}{l}\text { agricultural } \\
\text { cooperative }\end{array}$ & hawker & $\begin{array}{l}\text { total of } \\
\text { responses }\end{array}$ \\
\hline \multirow{2}{*}{ mag-geoli } & A 3.4 & 1.5 & 19.0 & 12.6 & 36.5 & 36.4 & 3.3 & 22.5 & 1.3 & 1,964 \\
\hline & B 17.6 & 5.6 & 43.0 & 13.0 & 79.2 & 16.3 & 1.2 & 2.8 & 0.5 & 1,883 \\
\hline \multirow[b]{2}{*}{ fish } & A 36.4 & 4.5 & 8.4 & 1.6 & 50.8 & 29.7 & 7.6 & 4.9 & 7.1 & 2,064 \\
\hline & В 65.5 & 9.7 & 11.8 & 1.8 & 88.8 & 4.1 & 1.6 & 0.6 & 4.9 & 1,979 \\
\hline \multirow[b]{2}{*}{ underwear } & A 25.6 & 5.3 & 17.5 & 2.1 & 50.6 & 33.2 & 9.3 & 4.4 & 2.5 & 2,044 \\
\hline & В 49.5 & 10.2 & 25.6 & 1.6 & 87.3 & 6.8 & 2.5 & 0.8 & 2.7 & 1,948 \\
\hline \multirow{2}{*}{ men's suits } & A 15.8 & 7.0 & 21.5 & 0.9 & 45.2 & 40.3 & 11.4 & 1.8 & 1.3 & 1,895 \\
\hline & B 30.1 & 9.9 & 41.3 & 2.3 & 83.6 & 11.7 & 3.2 & 0.7 & 0.8 & 1,797 \\
\hline \multirow[b]{2}{*}{ shoes } & A 16.0 & 5.9 & 22.3 & 1.0 & 45.1 & 42.0 & 9.5 & 2.2 & 1.2 & 1,939 \\
\hline & В 30.3 & 8.9 & 42.1 & 1.6 & 82.9 & 12.5 & 3.1 & 0.8 & 0.7 & 1,823 \\
\hline
\end{tabular}

Source: after the questionnaire 
Table 6. The comparison of traffics for visiting the purchasing facilities between the present time (A) and ten years ago (B).

\begin{tabular}{llccccccc}
\hline \hline & & $\begin{array}{c}\text { foot } \\
\%\end{array}$ & $\begin{array}{c}\text { bicycle } \\
\%\end{array}$ & $\begin{array}{c}\text { autocycle } \\
\%\end{array}$ & $\begin{array}{c}\text { private car } \\
\%\end{array}$ & $\begin{array}{c}\text { bus } \\
\%\end{array}$ & $\begin{array}{c}\text { train } \\
\%\end{array}$ & $\begin{array}{c}\text { total of } \\
\text { responses }\end{array}$ \\
\hline \multirow{2}{*}{ mag-geoli } & $\mathrm{A}$ & 44.3 & 8.8 & 4.0 & 1.0 & $41.4^{*}$ & 0.2 & 1,607 \\
& $\mathrm{~B}$ & 63.0 & 13.4 & 1.7 & 0.6 & 20.8 & 0.4 & 1,541 \\
fish & $\mathrm{A}$ & 16.6 & 5.4 & 3.7 & 1.0 & 70.3 & 0.1 & 1,684 \\
& $\mathrm{~B}$ & 50.5 & 11.5 & 1.2 & 0.3 & 35.4 & 0.9 & 1,615 \\
\multirow{5}{*}{ underwear } & $\mathrm{A}$ & 15.1 & 4.9 & 4.8 & 1.0 & 73.7 & 0.4 & 1,649 \\
& $\mathrm{~B}$ & 45.8 & 12.1 & 1.2 & 0.8 & 38.8 & 1.3 & 1,779 \\
\multirow{5}{*}{ shen's suits } & $\mathrm{A}$ & 13.6 & 4.0 & 5.6 & 1.8 & 74.3 & 0.6 & 1,780 \\
& $\mathrm{~B}$ & 41.8 & 11.2 & 1.5 & 1.0 & 42.6 & 1.9 & 1,511 \\
& $\mathrm{~A}$ & 13.6 & 4.2 & 5.3 & 1.5 & 74.6 & 0.8 & 1,583 \\
& $\mathrm{~B}$ & 42.7 & 11.3 & 1.3 & 0.8 & 42.7 & 1.3 & 1,518 \\
\hline
\end{tabular}

* The value is questionable.

Source: after the questionnaire

establishments are utilized more frequently by the inhabitants of the surrounding rural area than by the inhabitants of the central area.5)

\section{Service areas of goods and services}

Considering the results of the previous research, purchasing places, kinds of purchasing stores and traffic facilities for mag-geoli (a kind of Korean liquor made of rice), fish, underwear, men's suits and shoes have been analysed. Table 5 shows that mag-geoli, underwear, men's suits and shoes are mostly purchased in a permanent store without market days in contrast with fish which has the highest purchasing ratio in periodic markets. Because the purchasers of mag-geoli mainly go to shop on foot in contrast with the purchasers of underwear, men's suits and shoes who mainly go to shop by bus as shown in Table 6, we can estimate that people buy mag-geoli in their own school districts. Therefore, the authors describe mag-geoli, fish and men's suits as typical goods in this research. These purchases are characterized as follows:

1) Mag-geoli As mentioned above, it is a purchasing good of the lowest order mainly obtained from permanent stores. Its present purchasing ratio on market days has decreased to $36.5 \%$, the lowest ratio of the five goods under consideration (Table 5). The inhabitants within the school districts who purchase over $60 \%$ of mag-geoli within their own area amount to $45.8 \%$ of all 59 school districts. Relatively large central places such as Yicheon,
Janghowon, Gamgok, Muguk and Umseong expand their purchasing areas to surrounding school districts, as shown in Figure 4.

Nowadays the purchase of mag-geoli is usually undertaken on foot from permanent stores or agricultural cooperatives without market days.

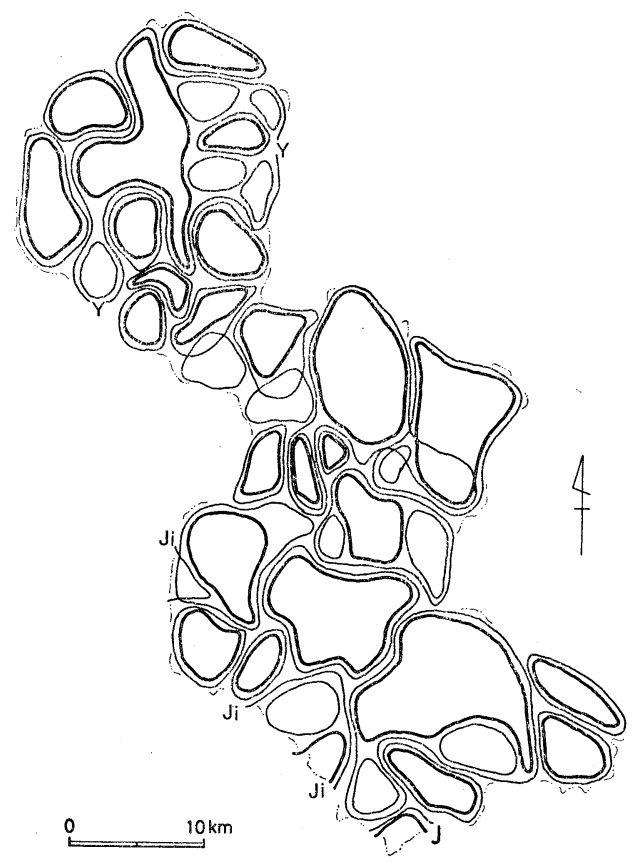

Figure 4. The purchasing areas of mag-geoli. The thick and thin lines show the iso-dependence ratios of $60 \%$ and $30 \%$ respectively (the rest is omitted).

Ji: Jincheon J: Jungpyeong Y: Yicheon Source: after the questionnaire 
But in some large purchasing areas as mentioned above, people occasionally go by bus. During the last ten years the purchasing ratio within the immediate inhabited area has gradually increased; 17 school districts show distinct increases of more than $10 \%$.

2) Fish As mentioned above, it is typically purchased at periodic markets. Therefore its purchasing areas are consequently the surroundings of the periodic market (Figure 5). ${ }^{6)} \quad$ Yicheon, Janghowon and Umseong have large purchasing areas which have further been expanded to the surrounding school districts during the past ten years. But the purchasing areas of other periodic markets remain within their own school districts. Less than $60 \%$ of the inhabitants come to purchase at a small periodic market like Daeso. Many of the inhabitants in both the myeons of Daeso and Maengdong visit Jincheon $u p$, a central place of higher order which lies outside the area of this survey.

Half of the significant respondents purchase fish on market days and $36 \%$ visit periodic

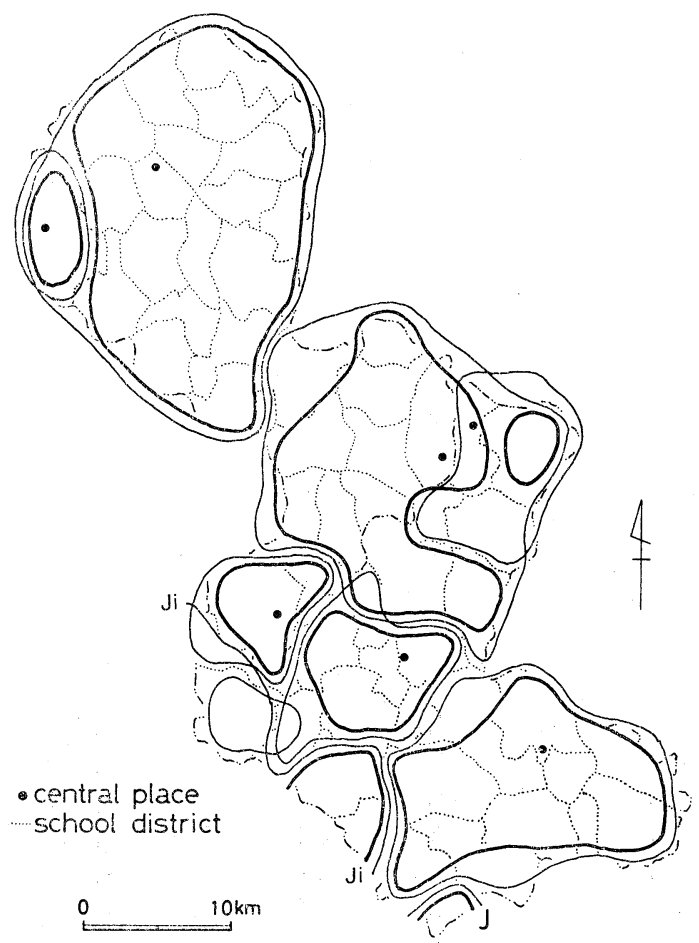

Figure 5. The purchasing areas of fish.

Ji: Jincheon J: Jungpyeong Source: after the questionnaire markets, though the utilization of market days and periodic markets has obviously decreased in the past ten years.

3) Men's suits Figure 6 shows that the purchasing areas of men's suits are similar to those of fish ${ }^{7}$ except for the omission of two small periodic markets: Ocheon and Daeso. In Gamgok near the central place of higher order Janghowon, the purchasing area of over $60 \%$ is not within its own school district but rather is concentrated in the eastern part representing an eccentric purchasing pattern.

Compared to the purchase behavior of ten years ago the purchasers in permanent stores without market days have increased as well (Table 5). According to the analyses of the school district units the purchase of men's suits in permanent stores without market days is dominant in $67.8 \%$ of all school districts.

Although the correlation coefficient is very low $\left(r=0.353^{*}\right)$ between the purchase ratio of men's suits on market days and the ratio of full-time peasants plus side-business peasants in each school district, it can be assumed, that

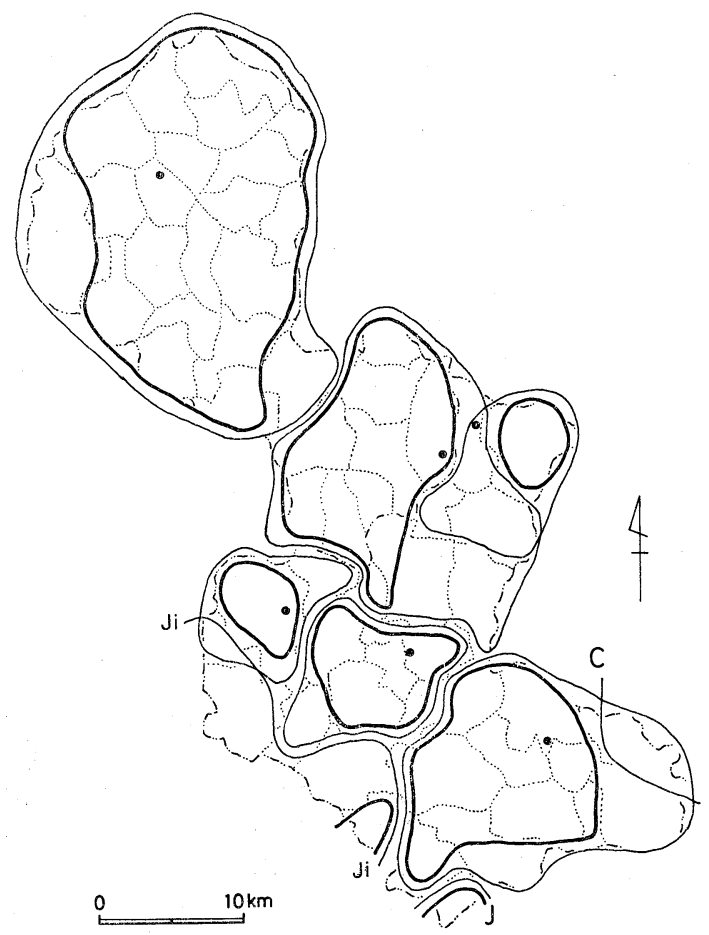

Figure 6. The purchasing areas of men's suits.

C: Chungju Ji: Jincheon J: Jungpyeong Source: after the questionnaire 
the inhabitants near periodic markets purchase men's suits in permanent stores irrespective of market days whereas the peasants remote from periodic markets tend to mainly purchase on market days.

4) Medical service areas The service areas of dentists and doctors (for tympanitis and appendicitis) are so similar to each other that in this paper the service areas of dentists are discussed as representative of both. In the previous study it was recognized that the service areas of dentists were larger than the purchasing areas of men's suits and that during the last ten years the two largest central places had expanded their service areas at the expense of other small central places. In contrast with this feature there appear to be no distinct differences between the service areas of dentists and the purchasing areas of men's suits in this survey area; the only small difference is that less than $60 \%$ of the inhabitants in Samseong and the surrounding areas utilize at dentist as shown in Figure 7.

During the last ten years Yicheon and Janghowon have intensified the dependence ratio from the surrounding areas and have a tendency to expand their service areas whereas in Gamgok and Samseong the dependence ratio has decreased. On the other hand most of the people who had taken only medicine for toothaches ten years ago, have now gotten into the habit of visiting a dentist by bus. ${ }^{8}$ This significant shift in dental treatment has occurred in 14 school districts or $23.7 \%$ of the survey area. These school districts are main- ly located in the southern part of the survey area. Such change is not different from the changes found in the previous survey area. Thus it is considered that the socioeconomic conditions of this survey area, particularly in the south, are not more highly developed in spite of their location closer to Seoul than those of the previous survey area.

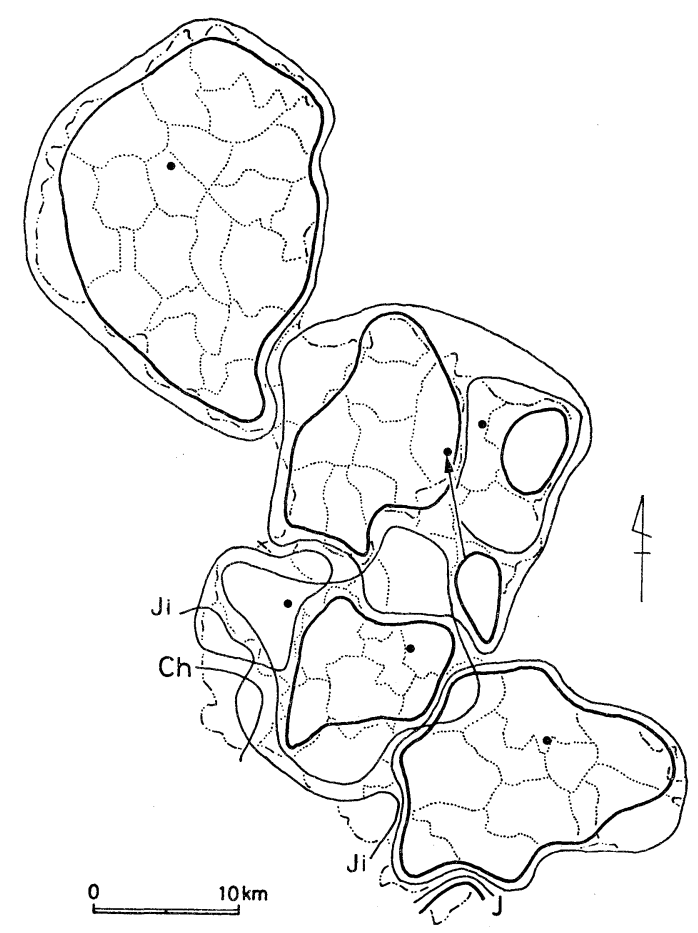

Figure 7. The service areas of dentists. Ch: Cheongju Ji: Jincheon J: Jungpyeong Source: after the questionnaire

Table 7. The comparison of selling features of agricultural products between the present time (A) and ten years ago (B).

\begin{tabular}{|c|c|c|c|c|c|c|c|c|c|c|c|}
\hline & & \multicolumn{5}{|c|}{ selling on market days $(\%)$} & \multicolumn{5}{|c|}{ selling without market days $(\%)$} \\
\hline & & $\begin{array}{l}\text { periodic } \\
\text { market }\end{array}$ & $\mid \begin{array}{l}\text { shifting } \\
\text { merchant }\end{array}$ & $\begin{array}{l}\text { stable } \\
\text { merchant }\end{array}$ & $\begin{array}{l}\text { agricultu- } \\
\text { ral coope- } \\
\text { rative }\end{array}$ & total & merchant & broker & \begin{tabular}{|l|} 
agricultu-|h \\
ral coope- \\
rative
\end{tabular} & hawker $\left.\right|_{\mathrm{t}} ^{\mathrm{t}}$ & $\begin{array}{l}\text { total of } \\
\text { responses }\end{array}$ \\
\hline \multirow{2}{*}{ vegetable } & $\mathrm{A}$ & 16.8 & 19.5 & 12.7 & 3.8 & 52.8 & 27.6 & 14.3 & 5.3 & - & 1,442 \\
\hline & B & 29.1 & 38.5 & - & 18.9 & 86.5 & 3.6 & 4.5 & 3.9 & 1.4 & 1,330 \\
\hline \multirow{2}{*}{ egg } & A & 9.3 & 13.2 & 19.9 & 6.8 & 49.1 & 31.4 & 11.5 & 8.0 & - & 1,151 \\
\hline & $\mathrm{B}$ & 22.2 & 27.0 & - & 32.6 & 81.1 & 6.6 & 6.8 & 3.2 & 1.6 & 1,107 \\
\hline \multirow{2}{*}{ cattle } & $\mathrm{A}$ & 23.9 & 19.2 & 1.9 & 11.7 & 56.8 & $3.6^{*}$ & 26.7 & 12.7 & - & 1,501 \\
\hline & B & 36.5 & 30.4 & - & 3.5 & 70.4 & 15.8 & 1.1 & 10.1 & 2.6 & 1,412 \\
\hline \multirow{2}{*}{ pig } & A & 16.9 & 20.7 & 4.1 & 12.1 & 53.8 & $5.3^{*}$ & 25.6 & 15.3 & - & 1,338 \\
\hline & B & 29.1 & 33.6 & - & 5.3 & 68.0 & 15.9 & 2.3 & 9.4 & 4.4 & 1,242 \\
\hline
\end{tabular}

* The values are questionable. But the percentage is very low. Source: after the questionnaire 
Table 8. The relations between the sales of agricultural products (a) and the purchases of goods (b).

\begin{tabular}{clrrrrrr}
\hline (a) & \multicolumn{1}{c}{ (b) } & A & B & C & D & total & phi \\
\hline \multirow{3}{*}{ vegetables } & mag-geoli & 27.6 & 25.4 & 9.2 & 37.7 & $100(1,376)$ & 0.335 \\
& fish & 38.1 & 14.3 & 13.2 & 34.3 & $100(1,422)$ & 0.448 \\
& underear & 37.1 & 15.2 & 14.1 & 33.6 & $100(1,406)$ & 0.413 \\
& men's suits & 34.4 & 17.0 & 13.0 & 35.6 & $100(1,339)$ & 0.402 \\
cattle & shoes & 33.8 & 18.0 & 13.7 & 34.5 & $100(1,353)$ & 0.368 \\
& mag-geoli & 27.9 & 28.9 & 9.1 & 34.1 & $100(1,444)$ & 0.288 \\
& fish & 38.8 & 17.8 & 12.7 & 30.7 & $100(1,483)$ & 0.390 \\
& underwear & 38.8 & 17.9 & 13.3 & 30.0 & $100(1,473)$ & 0.374 \\
& men's suits & 34.3 & 22.0 & 13.5 & 30.2 & $100(1,404)$ & 0.297 \\
& shoes & 34.9 & 21.2 & 12.8 & 31.1 & $100(1,424)$ & 0.329 \\
\hline
\end{tabular}

A: (a) and (b) are undertaken on market days B: Only (a) is undertaken on market days C: Only (b) is undertaken on market days D: Both of (a) and (b) are not undertaken on market days phi: phi-coefficient between (a) and (b) in the case of A Source: after the questionnaire

\section{Collecting areas of agricultural products}

Table 7 shows where and to whom vegetables, eggs, cattle and pigs are sold. Table 7 indicates that about one half of the agricultural products are still sold on market days and that the collecting function of agricultural products is maintained in periodic markets, although there exists an increasing tendency to sell agricultural products directly to merchants and brokers without participating on market days.

Table 8 shows how the selling activities of vegetables and cattle on market days are related to the purchasing activities of necessary goods. The highest phi-coefficient is found between vegetables and/or cattle and fish, though the value is not high. Therefore, it is assumed that peasants who sell vegetables and cattle on market days probably purchase fish there at the same time. However, as there is little relationship between the sale of agricultural products and the purchase of men's suits and/or mag-geoli both activities may take place on different days and at different places.

1) Vegetables Radishes and Chinese cabbage are the main vegetables sold by peasants in this area. These vegetables are transported to the consuming areas by merchants and brokers. Figure 8 indicates the collecting areas of vegetables as defined by the analysis of the questionnaires. According to Figure 8 the collecting areas correspond more directly to the purchasing areas of fish than any other service areas of goods. However, in the school districts such as Saengguk and Wonnam the selling ratio of vegetables in each district accounts for $30 \%$ of total sold despite the lack of periodic markets. On the other hand, more than $30 \%$ of the peasants in the school districts of Jangcheon and Yul send their vegetables to Seoul. The reliability of the information provided by the questionnaire

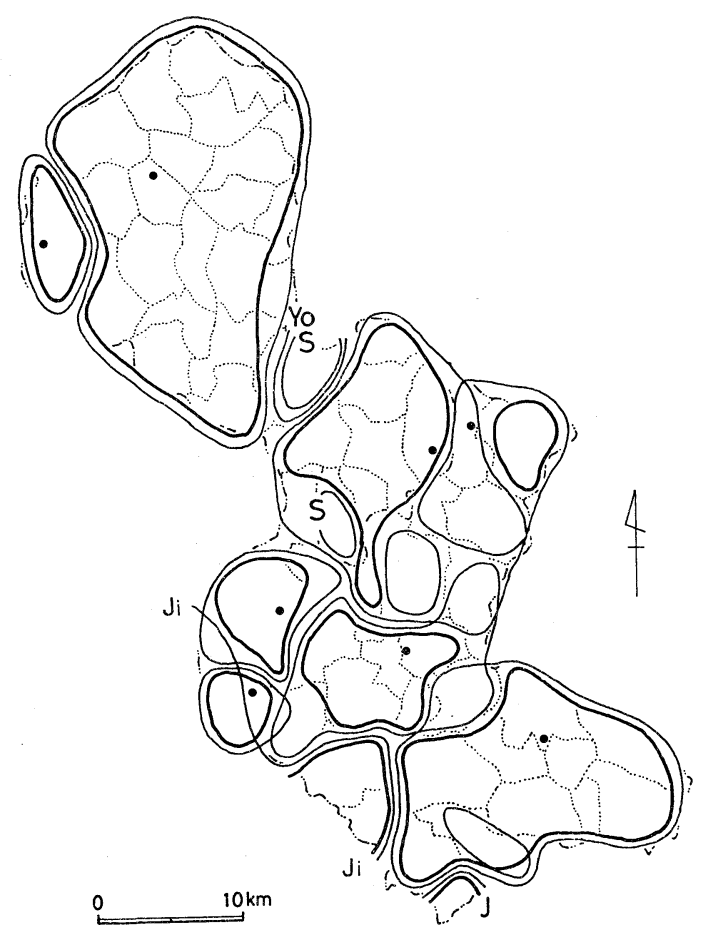

Figure 8. The collecting areas of vegetables.

Ji: Jincheon J: Jungpyeong S: Seoul Yo: Yoju Source: after the questionnaire 
regarding the collecting areas of vegetables is questionable.

There are two types of vegetable collection; the dominant type is the selling to permanent stores and brokers without market days. The other is the selling to market merchants and in periodic markets. It seems that such selling methods of vegetables in this servey area are far more complex than in Japan where modern selling organizations through agricultural cooperatives and the like have already been well established.

2) Cattle As the trade of cattle is conducted at cattle markets the collecting areas are related closely to the spatial distribution of cattle markets. The collecting areas of cattle in Figure 9 resemble the purchasing areas of men's suits (Figure 6) and the service areas of dentists (Figure 7). However, they indicate a distributional feature considerably different from the previous survey area in which they corresponded to central functions of a slightly lower order due to the existence of many small cattle markets. The trade of cattle has recently been decreasing in small cattle markets such as Samseong and Muguk whereas the trade of domestic animals in public markets of cooperative type ${ }^{9)}$ established recently in more than one myeon of every gun tend to increase in volume.

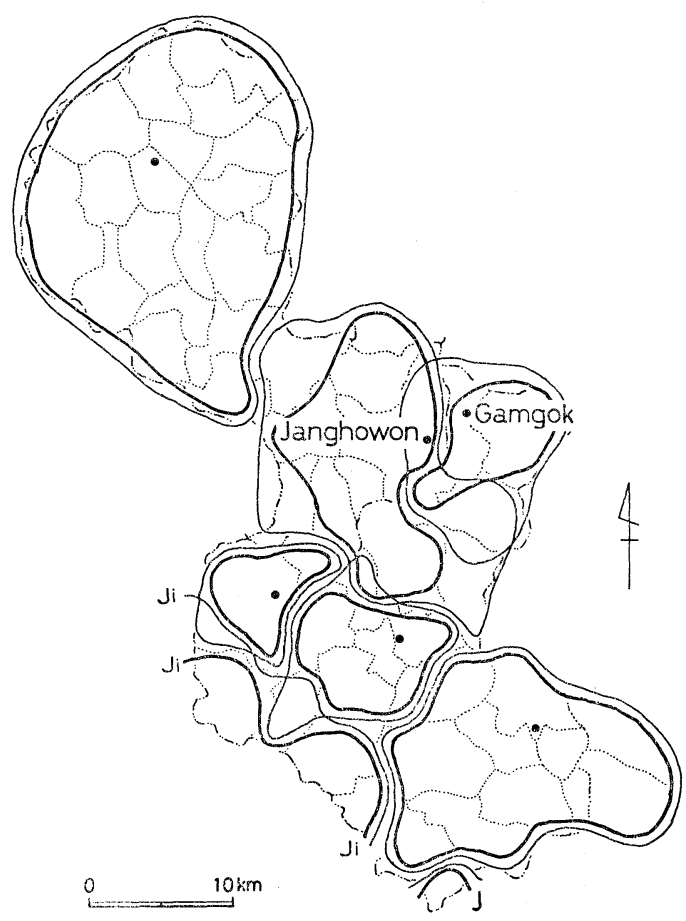

Figure 9. The collecting areas of cattle.

Ji: Jincheon J: Jungpyeong Source: after the questionnaire

Table 9. The relations between the visiting frequency per month and the staying times in a periodic market.

\begin{tabular}{|c|c|c|c|c|c|c|c|c|}
\hline times & $\begin{array}{l}\text { under } \\
0.5 \text { hour }\end{array}$ & $0.5-1.0$ & $1.0-2.0$ & $2.0-3.0$ & $3.0-5.0$ & $\begin{array}{l}\text { over } \\
5.0 \mathrm{hrs}\end{array}$ & total & $\begin{array}{l}\text { mean staying } \\
\text { time (hours) }\end{array}$ \\
\hline 0 & 0.1 & 0.2 & 0.1 & 0.1 & 0.1 & 0.1 & $0.7\left(\begin{array}{ll}\% & 14\end{array}\right)$ & 1.75 \\
\hline $1-2$ & 1.4 & 6.6 & 13.3 & 14.9 & 5.2 & 1.3 & $42.7(760)$ & 2.05 \\
\hline $3-4$ & 1.1 & 7.4 & 12.3 & 14.8 & 5.5 & 1.7 & $42.9(762)$ & 2.20 \\
\hline $5-6$ & 0.7 & 3.2 & 4.2 & 3.3 & 1.1 & 1.1 & $13.6(242)$ & 1.95 \\
\hline total & 3.4 & 17.4 & 30.0 & 33.2 & 11.9 & 4.2 & $100.0(1,778)$ & 2.05 \\
\hline
\end{tabular}

Source: after the questionnaire

Table 10. The relations of visiting frequency between periodic and permanent markets (per month).

\begin{tabular}{|c|c|c|c|c|c|c|c|}
\hline periodic market & 0 & $1-2$ & $3-5$ & $6-10$ & $11-20$ & $\begin{array}{l}\text { almost all } \\
\text { days }\end{array}$ & total \\
\hline 0 & 0.4 & 0.3 & 0.1 & 0.1 & - & - & $0.8 \%$ \\
\hline $1-2$ & 9.0 & 26.0 & 5.8 & 0.8 & 0.3 & 0.2 & $42.2(700)$ \\
\hline $3-4$ & 5.4 & 22.3 & 11.5 & 2.4 & 0.4 & 0.7 & $42.7(707)$ \\
\hline $5-6$ & 1.2 & 4.1 & 4.8 & 2.1 & 0.8 & 1.1 & $14.1(234)$ \\
\hline total & 16.0 & 52.7 & 22.2 & 5.4 & 1.6 & 2.0 & $100.0(1,659)$ \\
\hline
\end{tabular}

Source: after the questionnaire 


\section{The patrons of periodic markets and their behaviors}

As Table 9 shows, people visit periodic markets in the survey area normally one to four times per month and stay during one to three hours on the average. Furthermore, the reverse correlation is recognized between the visiting frequency and the staying time for periodic markets. The correlation coefficient of $-0.515^{*}$ was obtained by the analysis of the school district units; the inhabitants of school districts who frequently visit a periodic market do not stay a long time. Since people visit a permanent market in proportion to the number of times they visit a periodic market, it can be estimated that both kinds of markets are patronized by each inhabitant (Table 10). A high correlation coefficient of $0.643^{*}$ between the visiting fre- quencies of both the markets is obtained; the more frequently the inhabitants of a school district visit a periodic market, the more frequently they also visit a permanent market. Therefore it does not mean that permanent markets have taken the place of periodic markets but rather they exist side by side.

Moreover, in this area as well as in the previous survey area periodic markets are patronized mainly by peasants. The staying time in a periodic market is longest for fulltime peasants; the significant difference between time spent in markets by peasants and non-peasants is presented in Table 11. From the analysis of each school district unit it can also be concluded, with a high correlation coefficient of $0.696^{*}$, that the more full-time and side-business peasants there are in a school district, the longer the staying time per person in a periodic market. This may be

Table 11. The relations between the staying time, the sale of agricultural products in a periodic market and the kind of farmhouses.

\begin{tabular}{|c|c|c|c|c|c|c|c|c|}
\hline & $\begin{array}{l}\text { under } \\
0.5 \mathrm{hr} \text {. }\end{array}$ & $0.5-1.0$ & $1.0-2.0$ & $2.0-3.0$ & $3.0-5.0$ & $\begin{array}{l}\text { over } \\
5.0 \text { hrs }\end{array}$ & total & $\begin{array}{l}\text { mean stay- } \\
\text { ing time }\end{array}$ \\
\hline & & & & & & & $\%$ & \\
\hline $\begin{array}{c}\text { (1) full-time farm } \\
\text { households }\end{array}$ & 0.7 & 3.7 & 9.7 & 15.7 & 6.3 & 2.1 & $38.2(630)$ & 2.43 \\
\hline \multicolumn{9}{|l|}{$\begin{array}{c}\text { part-time farm } \\
\text { households }\end{array}$} \\
\hline (2) of mainly farming & 0.8 & 3.7 & 7.2 & 9.6 & 2.9 & 1.5 & $25.7(\quad 424)$ & 2.21 \\
\hline (3) of mainly other jobs & 0.4 & 2.5 & 3.9 & 2.6 & 0.9 & 0.3 & $10.6(174)$ & 1.85 \\
\hline (1) $+(2)$ & 1.5 & 7.4 & 16.9 & 25.3 & 9.2 & 3.6 & $64.9(1,054)$ & 2.34 \\
\hline (4) non-farm households & 1.6 & 7.2 & 8.6 & 5.5 & 2.1 & 0.4 & $25.5(420)$ & 1.70 \\
\hline total & 3.5 & 17.1 & 29.4 & 33.5 & 12.1 & 4.3 & $100.0(1,054)$ & 2.13 \\
\hline A & 3.0 & 12.2 & 24.3 & 38.0 & 16.4 & 6.0 & $100.0(629)$ & 2.38 \\
\hline $\mathrm{B}$ & 3.5 & 18.5 & 32.7 & 31.8 & 10.4 & 3.1 & $100.0(1,006)$ & 1.98 \\
\hline total & 3.3 & 16.1 & 29.5 & 34.2 & 12.7 & 4.2 & $100.0(1,635)$ & - \\
\hline
\end{tabular}

A: the respondents who frequently sell their agricultural products in a periodic market.

B: the respondents who do not so much sell their agricultural products in a periodic market. Source: after the questionnaire

Table 12. The relations between the kind of farm households and the visiting frequency of periodic markets (per month).

\begin{tabular}{|c|c|c|c|c|c|c|}
\hline $\begin{array}{ll}\text { kind of farm households } & \text { visiting frequency }\end{array}$ & 0 & $1-2$ & $3-4$ & $5-6$ & total & $\begin{array}{l}\text { mean visiting } \\
\text { frequency }\end{array}$ \\
\hline $\begin{array}{l}\text { (1) full-time peasant households } \\
\text { part-time peasant households }\end{array}$ & 0.3 & 17.8 & 17.5 & 2.6 & $38.2(619)$ & 2.67 \\
\hline (2) of mainly farming & 0.3 & 11.4 & 10.4 & 3.8 & $25.9(420)$ & 2.87 \\
\hline (3) of mainly other jobs & 0.1 & 4.1 & 4.6 & 2.0 & $10.7(174)$ & 3.07 \\
\hline (1) $+(2)$ & 0.6 & 29.2 & 27.9 & 6.4 & $64.1(1,039)$ & 2.75 \\
\hline (4) non-peasant households & 0.2 & 10.0 & 9.9 & 4.9 & $25.1(406)$ & 3.07 \\
\hline total $(\%)$ & 0.9 & 43.3 & 42.5 & 13.3 & $100.0(1,619)$ & 2.86 \\
\hline
\end{tabular}

Source: after the questionnaire 
dependent upon the fact that respondents who frequently sell their agricultural products in a periodic market stay at the market for a longer time. In analysing each school district there is a correlation of $0.434 *$ between the selling ratios and the staying time in periodic markets.

However, it should be noted that peasants do not often visit periodic markets. As shown in Table 12 the most frequent visitors are nonpeasants and worker peasants. Similarly, in seeking the correlation coefficient of the ratio of full-time plus side-business peasants with the visiting frequency of periodic and permanent markets in school district units, the correlation coefficient of the former is $-0.552^{*}$ and of the latter $-0.655^{*}$. Between the ratio of the respondents who frequently sell their agricultural products in a periodic market and the visiting frequency to a periodic market, there exists a low correlation of only $-0.302 *$.

The reasons that peasants do not frequently visit periodic markets are that it is not necessary for them to visit periodic markets on every market day in order to sell their products and the lack of free time for such visits. In addition, many of them live far from periodic or permanent markets. On the contrary, nonpeasants and worker peasants who live in closer proximity to periodic and permanent markets frequently visit them. As a result the commercial activities of permanent markets and stores become prosperous on market days.

In the previous study the authors concluded, that traditional functions of collecting agricultural products and purchasing goods are closely connected in periodic markets because the purchasing areas of goods correspond to the collecting areas of agricultural products. This is in contrast to the service areas of dentists which have obviously expanded during the past ten years. Although the difference

Table 13. The visitors of periodic market (\%).

\begin{tabular}{lc}
\hline housemaster & 14.6 \\
wife & 78.7 \\
grandfather & 2.4 \\
grandmother & 3.1 \\
others & 1.0 \\
no visits & 0.2 \\
total & $100.0(1,934)$ \\
\hline Source: after the questionnaire
\end{tabular}

Source: after the questionnaire between these three areas is not so clear in this survey area, it can be stated that, because of the close tie between peasants and periodic markets, market days are still very important to the peasants in current lifestyles.

According to the analysis of the questionnaires, the visitors of periodic markets are mainly wives of peasants and non-peasants (Table 13). The frequency of their visits to periodic markets increased after the Korean War. From the length of time they spend at periodic markets, it can be assumed that these women also engage in some social activities during their visits unlike their husbands who engage in social activities at taverns.

\section{The developing process of the central place system}

As mentioned above, the functions of periodic markets are gradually decreasing in proportion to the decreasing sale of agricultural products there; it is estimated that not only the sale of agricultural products but also the purchase of goods on market days have gradually decreased as the lifestyles of the rural inhabitants have changed. Recent significant decreases of population in rural areas will not allow the traditional system of agricultural production to continue as before. Although generally speaking some periodic markets can be developed into permanent markets in the future, this is improbable in the survey area where four permanent markets have already been established. On the other hand, commercial facilities are considerably located in settlements such as Hyunbang, Hancheon, Pocheon and Maengdong where periodic markets were recently abolished (Table 4). Their central place functions have not been completely lost by the abolishment of periodic markets. In Figure 10 store and service facilities along the main street of Saengguk are shown; some new stores have recently been established at the site of the former market place. It seems that the functions for central places of lower order are gradually changing in order to adapt themselves to a modern system of central places formed after the decline of the traditional functions of periodic markets.

How are the changes in the central place 


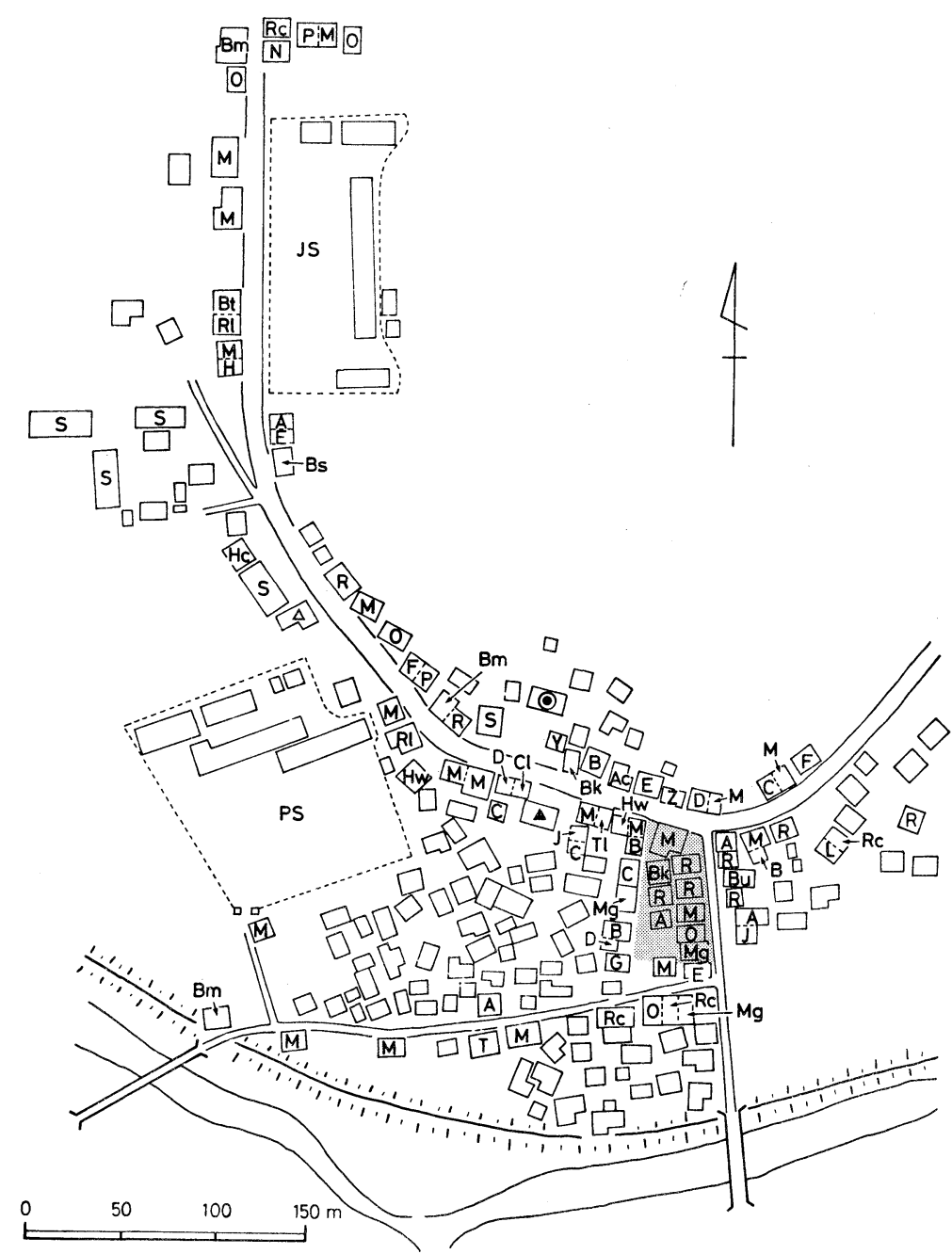

Figure 10. The distribution of central establishments in the central settlement of Saengguk.

former market place
$\odot$ myeon office
A police office
$\triangle$ post office
A: Farm appliances Ac: Agricultural chemicals B: Barber Bk: Banking Bm: Building materials Bs: Books Bt: Bus tickets Bu: Butcher C: Café $\mathrm{Cl}$ : Clothing D: Pharmacy E: Household electric appliances F: Fuel G: Frain H: Hospital (clinics) Hc: Health center Hw: Hardware J: Jewelry JS: Junior high school L: laundry M: Miscellaneous goods Mg: Mag-geoli $\mathrm{N}$ : Newspapers O: Offices P: Photo studio PS: Primary school R: Restaurant Rc: Rice cleaning Rl: Religious organi- zation S: Storehouse T: Training school Tl: Taylor Y: Toys $\mathrm{Z}$ : Billiard room Source: after the field survey

system which are marked by the decreasing functions of periodic markets characterized in comparison with that of central places of lower order in Japan? Although periodic markets declined in the early stages of modernization in most areas of Japan, it should not be said that the developing process of the central place system in Korea is very different from that of Japan. The central place system in Korea does not consist of periodic markets alone; 
they represent only a part of the functions within the system; in Korea, as well as in Japan, the national urban system is highly developed. In Japan also there are areas where the function of periodic markets remains even today. Therefore it can be stated that the low order functions of central places are provided mostly in the form of periodic markets as well as by permanent facilities.

This does not mean, however, that the central place system has developed through the same process of modernization in Korea as in Japan. Under the Japanese occupation (1910 -1945) Korean urbanization made rapid progress due to a persistent colonial policy. But the economic life of peasants, as well as the economic structure of agriculture, remained unaffected by the occupation and never made progress. Periodic markets remained a center of rural life. Therefore unbalanced economic development has taken place between rural and urban areas in Korea (Hong, 1979, pp. 1-39). It was after the liberation of the country in 1945 that the rural population was pushed toward large cities. Cities were unable to absorb the mass influx and the result was what DAvis and Golden (1954) termed over-urbanization. Thus in Korea the cities forming a higher order within the Korean urban hierarchy and the periodic markets of lower orders had grown in parallel at least before the liberation, whereas in Japan larger cities have persistently grown at the sacrifice of central places of low order since the Meiji era (Morikawa, 1967, 1971).

In the disordered time just after the Korean War periodic markets temporally increased in number but began to decrease after their peak in 1961 (KIm, 1977, p. 224) ${ }^{10)}$. Due to this, central places of relatively high order like the county (gun) seats of Yicheon and Umseong have extended their service areas whereas small scale periodic markets have lost their functions. Although over-urbanization took place immediately following the liberation, normal urbanization proceeded in time. During the period of rapid urbanization from 1966 to 1970 the population of guns has decreased for the first time since 1910. Such pull-type migration as seen in urban growth with resultant decrease of rural population is essen- tially different from the process of urbanization in developing countries. Hong (1979, pp. 69-92) pointed out that Korea has begun to progress from a developing country toward middle-developed or developed country since the onset of such rapid urbanization. As mentioned above, it was after 1976 that the population in this area began to decrease absolutely. Corresponding to this, central places of a higher order, such as Yicheon and Umseong, gradually developed difficulty of strengthening their centrality despite the expansion of their service areas.

In contrast to this process in Korea, a number of central places of low order in Japan have declined rapidly in the modernization process since the Meiji era (Morikawa, 1971); in particular, many of the traditional coaching and port towns have lost their functions in the process of traffic modernization. Nevertheless, it is incorrect to assume that rural Japan has been developed through a different process from that which took place in rural Korea. In rural Japan central places of low order in favorable local traffic locations have also been developed and have functioned as collecting places for agricultural products. They performed both functions of collecting agricultural products and selling goods: functions essentially similar to the dual functions of Korean periodic markets even though they were not periodic markets.

For example, the central place of low order Kuregatao located on the Jinseki plateau in Hiroshima Prefecture, performed both these functions and maintained a wider service area in the period before the Second World War than the present administrative area of Jinsekicho (municipality) (Morikawa, 1983). During the War the function of collecting agricultural and forestry products in Kuregatao was severely limited by war-time economic controls. However, its commercial activity flourished until about 1950 as a result of the increase of consumer population brought about by the evacuation of large cities and the number of Japanese returning from abroad. Kuregatao's population has steadily and rapidly declined since 1955. Surely it is only an example of the type of change which took place in central places of low order in mountainous part of 
rural Japan. Since it can be considered that most central places of low order in Japan had collecting functions of agricultural and forestry products before the Second World War, we can conclude that the recent decline of Korean periodic markets marks a developing process similar to that which occurred in the Japanese central place system.

It was after 1970 that the high economic growth period in Korea began in contrast with the period ten years earlier in 1967 when the rural population began to decrease rapidly in Japan. In the period from 1966 to 1971 the second five-year program of economic development in Korea was carried out and the rural population began to decrease rapidly as had previously occurred in Japan. The ratio of secondary and tertiary industrial population already exceeded $50 \%$ in 1971 . As seen from this process the onset of a high economic growth in Korea is at least five or six years later than in Japan. This growth period in Korea is now in progress. In addition, agriculture and rural life are influenced by the policy of trade liberalization and by the outflow of young people from rural areas. If the rapid decrease of population continues in this survey area, most of the central places will decline as they did in Japan. Yicheon gun is located near enough to Seoul to possibly be included into its metropolitan area in the future, unlike Umseong gun which has more rural characteristics.

\section{Conclusion}

The aim of the present paper is to clarify the characteristics of Korean central place system with its emphasis on central places of lower order, to define the roles of periodic markets within the system and to investigate more intensively the problems discussed by the authors in their previous research. The results obtained are summarized as follows:

1. Periodic markets in this survey area are located in unequal intervals from each other; there exist areas where people cannot reach any periodic market within a distance of $7 \mathrm{~km}$. There was no evidence to support the claim that periodic markets are oriented toward balanced distribution as a result of the abolishment of small scale periodic markets. Moreover, no periodic market located in remote distances from central places of higher order tends to maintain their activities as suggested in the previous research.

2. Analyzing the relation between the scale (turnover and number of visitors) of periodic markets and their central establishments in Umseong gun, it was found that central places of higher order such as Umseong, Gumwang, Gamgok and Samseong have a closer relationship than central places of lower order do. There is a central place of low order in Saengguk myeon which is equipped with a considerable number of establishments despite the absence of a periodic market. Central places of lower order do not completely lose their central functions when periodic markets are abolished. Thus it seems that a new system of central places consisting of myeon centers is being formed irrespective of the existence or non-existence of periodic market activities; the significance of periodic markets in this area is deminishing as compared with the previous research area.

3. Within this survey area the purchasing areas of mag-geoli are the smallest of all purchasing and service areas including the collecting areas of agricultural products. There are no distinct differences between service areas for each product and service except mag-geoli; the collecting areas for vegetables and cattle and the purchasing areas of fish and men's suits are similar to the service areas of dentists. Moreover, it is recognized that peasant's wives may sell vegetables and purchase fish on market days. In comparison with ten years ago the patrons of periodic markets for all goods and services decreased and the users of buses increased.

4. Non-peasants and worker peasants living in the vicinity of periodic markets tend to visit periodic and permanent markets more frequently than full-time and side-business peasants, because commercial activities of permanent markets and stores become more prosperous on market days. However, the full-time and side-business-peasants stay at periodic markets for longer times and are 
more dependant upon them than the nonpeasants and worker peasants.

5. The process of Korean urbanization is considerably different from that of Japan because it has experienced urbanization of a colonial type during the Japanese occupation. The Korean cities have grown as bases of colonial management irrespective of socioeconomic changes in rural areas. After the liberation urbanization in the true sense of the word began. In the process of urbanization periodic markets began to decline for the first time in the high economic growth period since their temporal rise following the Korean War. In contrast, Japanese urbanization has progressed at the sacrifice of central places of lower order since the Meiji era. However, central places of lower order in Japan had similar functions to Korean periodic markets. At latest after the Second World War central places of lower order in Japan lost the function of collecting agricultural products as a result of traffic development and the modernization of agricultural collecting systems. Their central functions also have declined because of the obvious decrease of the rural population which began with the onset of the high economic growth period. In this survey area a similar process will take place, although Yicheon gun may be included within the metropolitan area of Seoul in the future.

As the findings of the present paper do not always correspond to those of the previous research a number of case studies are required in order to obtain more comprehensive findings.

\section{Acknowledgments}

We are indebted to a number of persons, especially to Mr. Lee Guan Whan, the Chief of Educational Affairs for Yicheon gun, and also to Mr. Kim Jong CHANG, the Chief of the Education Affairs for Umseong gun for the distribution and collection of the questionnaire. We are also indebted to the 5 th grade teachers and to the parents of the primary school pupils in both Yicheon and Umseong guns for answering the questionnaires. We should also like to express our gratitude to the senior students of the Geographical Department of Chungbuk National University and to Mr. Toshitsugu $T_{A N A K A}$ and Mr. Shuichi TAKAIE, grad- uates of the Department of Geography of Hiroshima University, for their assistance in data processing. Finally the authors wish to acknowledge with gratitude to Miss Kathleen PAPPert and Prof. R.A. MAE for revision of English.

(Received May 27, 1985)

(Accepted July 30, 1985)

\section{Notes}

1) Korea is administratively divided into nine Dos and three special cities. A Do consists of several guns (county) and cities. A myeon and up are municipalities contained within a gun. Up is a small town with population of more than 20,000 . In a myeon there are administrative dongs or $r$ is and natural villages.

2) Purchasers in Seoul at the present time and ten years ago were 82 and 76 persons for shoes and 58 and 73 persons for men's suits in over one thousand respondents of questionnaires, respectively.

3) The developing movement of small towns corresponds with the Urban Planning Act for cities and the Saemaul Movement for rural communities. This movement aims to defend the outflow of population to large cities by improving living conditions and prospering shopping streets of small towns.

4) Questionnaire responses in which only a name of myeon or up was given as a purchasing and utilizing place were generally identified in the largest $r i$ of each myeon or up. In the case where neither periodic markets nor administrative centers of myeon exist in the $r i$, the responses were identified in the $r i$ with a periodic market. When the periodic market and administrative center are located in different $r i$ within a myeon such as Gamgok, the authors regarded the $r i$ with an administrative center as that place which was visited on non-market days. Though the authors occasionally made judgements regarding the places based on other questionnaires, there were no serious problems.

5) Gamgok is a typical example. As shown in Figure 5 to 8 it has an iso-dependence line of $60 \%$ in eccentric location.

6) Service areas of larger central places expand beyond the survey area. Therefore it is not clear if the iso-dependence lines exist just to the boundary lines of the survey area as shown in Figure 5 to 9 .

7) It depends on the fact that periodic markets of small scale are fewer in this area than in the previous survey area. In the previous survey area many periodic markets did not sell men's 
suits but did sell fish.

8) In the questionaire the authors asked the parents of the pupils, which they most frequently utilized when they had a toothache, the dentists, a pharmacy or a Chinese medicine store. Formerly only a few people visited dentists.

9) They have been established to modernize trade organization of domestic animals. They have a function to slaughter cattle and sell meat.

10) According to $\mathrm{K}_{\mathrm{IM}}$ (1977) the number of periodic markets in Korea changed from 549 in 1945, over 994 in 1961 to 952 in 1975 . In this survey area only Daeso and Saengguk were newly established after the Korean War.

\section{References}

Chosen Sotokufu (Governmentgeneral of Korea) (1924): Chosen no ichiba (Markets of Korea). Chosashiryo (Research data), 8, 664p.

Chosen Sotokufu (Government general of Korea) (1926): Shigaichi no shoken (Trade areas of urban settlements). Chosa-shiryo (Research data), 14, 574p.

Chosen Sotokufu (Governmentgeneral of Korea) (1929): Chosen no shijo keizai (Market economics of Kovea). Chosa-shiryo (Research data), 27, 527p.

Davis, K. and Golden, H.H. (1954): Urbanization and the development of preindustrial areas. Economic Development and Cultural Change, 3, 6-26.

Hong, K. (1979): Hanguk doshi yeongu (A research monograph on Korean cities). Alumni Association, Department of Geography, Kyungpook National University, Daegu, 468p.

Ishinara, H. (1977): Ichi (market) kenkyu no kinnen ni okeru tenkai -1967nen-1976nen (Recent development of the study on traditional markets: 19671976). Jimbun Chivi (The Human Geography), 29, 617-649.

Jeon, K. (1982): Kankoku Chuseihoku Do chiiki ni okeru seikatsuken oyobi teikiichi no henyo ni kansuru kenkyu (The study on the changing pro- cesses of the activity space and the periodic market in Chung-cheong Buk Province, Korea). Chirigaku Hyoron (Geographical Review of Japan), 55, 292312.

JEon. K. (1983): Kankoku Chuseihoku Do chiiki ni okeru chushinchi shisutemu no henyo ni kansuru kenkyu (A study on the changing process of the central place system in Chung-cheong Buk province). Chirigaku Hyoron (Geographical Review of Japan), 56, 471-495.

KIM, S. (1977): Hanguk nongcheon shijang eui jaedowa ginung (The structure and functioning of rural periodic markets in Korea). Nogyokeizai Kenkyuhokoku (Agricultural Economics, Research Papev), 88, 434p.

Morikawa, H. (1967): Oita ken ni okeru chushinchi kaiso no sen-i (Ecological changes of central place hierarchy in Oita prefecture). Tohoku Chivi (Annals of the Tohoku Geographical Association), 19, 114124.

Morikawa, H. (1971): Entwicklungstypen der zentralörtlichen Hierarchie in Japan. Zeitschrift für Wirtschaftsgeographie, 2/1971, 48-59.

Morikawa, H. (1980): Chushinchi von (The development of central place studies) I, II. Taimeido, Tokyo, $466 \mathrm{p}$.

Morikawa, H. (1983): Hiroshima ken Jinseki cho ni okeru kasoka to chushinshuraku no henbo (The process of depopulation and the change of central place in Jinseki municipality, Hiroshima Prefecture). Naikai Bunka Kenkyu Kiyo (Bulletin of the Institute for Cultural Studies of the Seto Inland Sea, Hiroshima University), 11, 25-58.

Morikawa, H. and Sung, J. (1982): Kankoku ChuseiNan Do Koshu fukin no chushinchi shisutemu to teikiichi (Central places and periodic markets in the surrounding areas of Kongju in Chung Cheong Nam Do, Korea). Chirigaku Hyoron (Geographical Review of Japan), 55, 757-778.

Mun, J. (1941): Chosen no ichiba (Markets of Korea). Nihon-Hyoronsha, Tokyo, 322p.

\section{ソウル南東郊外地域における中心地と定期市}

$$
\text { 森川洋*・成俊 鏞** }
$$

定期市研究では市場の制度や移動商人の研究が中心を なしてきたが，利用者に関する研究も必要である.特 飞, 都市システムの発達した韓国の定期市は低次中心地 として利用されて扮り, 中心地としてとらえられる。
忠清南道公州付近の定期市に関する前回の調查では, 定期市は生活必需品の分配と農畜産物の集荷の両機能を もつもので, 周辺地域活居する農民によって支光られ ているとしたが, 本研究に执いても注ぼ同様の結論を得

* 干730 広島市中区東千田町 広島大学文学部地理学教室

** 310 大韓民国忠清北道清州市開新洞山48 忠北大学校師範大学地理教育科 
た.すなわち, ソウル市の南東 50 ～ $100 \mathrm{~km}$ にある本地 域では, 定期市の訪問回数は專業農家よりもその近くに 住む農家の方が多いが, 定期市滞在時間では農畜産物の 販売をかねた専業農家の方が長く, 農家の生活にとって は重要な役割を果しているものと考えられる.

日本の低次中心地でも，第 2 次大戦前には農畜産物の 集荷機能をもち，低次中心地としての機能は類似したも のであった.ただし，日本では都市化の過程で早期に低 次中心地が衰退したのに対して，日本統治時代の韓国で は農村は旧態依然とした姿をとどめたままで都市化が進 行し，伝統的な低次中心地が長く存続してきたものと考
えられる・

しかし最近10年間には定期市の利用は著しく減少して おり，廃市後の集落にもサービス施設が設置され，新し い中心地システムが形成されつつある．本地域では今日 人口流出が増加し，また住民の生活圈も拡大して和り， 定期市や低次中心地は将来深刻な打撃を受けることが予 想される。

な物，本研究は昭和58～59年度文部省科学研究費「韓 国に打ける中心地システムと定期市」; 課題番号 :一般 研究 (C) 58580180 の補助を受けている. 